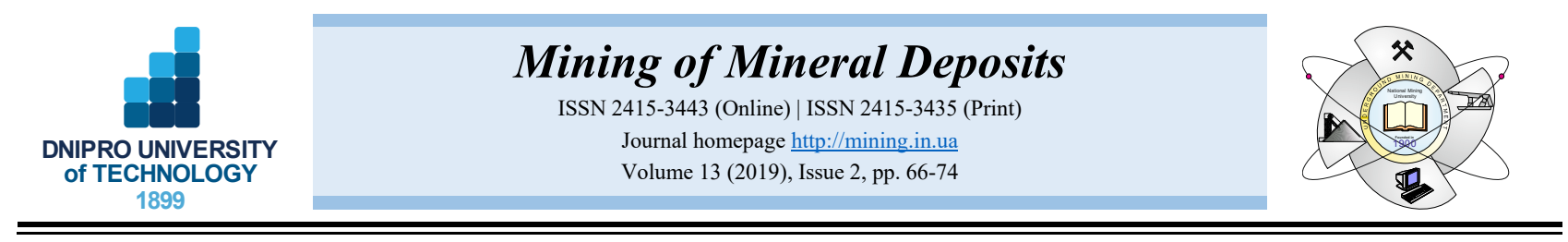

UDC 622.013:336.25

https://doi.org/10.33271/mining13.02.066

\title{
DISTRIBUTION OF MINERAL EXTRACTION REVENUE: OVERVIEW OF INTERNATIONAL PRACTICE
}

\author{
V. Churin ${ }^{1 *}$, N. Vysotskaya ${ }^{2}$, Yu. Sizova ${ }^{3}$, E. Danilina ${ }^{4}$, D. Gorelov ${ }^{5}$ \\ ${ }^{1}$ Moscow Automobile and Road Construction State Technical University, Moscow, Russian Federation \\ ${ }^{2}$ Moscow Metropolitan Governance University, Moscow, Russian Federation \\ ${ }^{3}$ Plekhanov Russian University of Economics, Moscow, Russian Federation \\ ${ }^{4}$ MIREA - Russian Technological University, Moscow, Russian Federation \\ ${ }^{5}$ Institute of Educational Technologies and Humanities, Moscow, Russian Federation \\ *Corresponding author: e-mail churinvv@yandex.ru, tel. +84991550104
}

\begin{abstract}
Purpose. To study basic principles and conditions of the efficiency of the system to redistribute mineral extraction revenue including the countries with lower levels of welfare.

Methods. The research applies a method of qualitative and quantitative analysis of the scientific literature, data by the Natural Resource Governance Institute, national reports according to the Extractive Industries Transparency Initiative, and open Internet sources. Taxation schemes for mineral extraction revenue as well as the most important tendencies in the schemes changes over the recent years were considered. Distributions of the resource taxes in terms of the state administration levels as well as vertical distribution of budget receipts from the development of natural resources were analyzed. The countries distributing tax receipts from the mineral extraction in favour of the local authorities were selected as the object of the research.

Findings. It has been determined that in the majority of countries, payments from mineral extraction are sent to the national-level institutions being distributed back to the mining areas or neighbouring territories. It has been pointed out that certain countries send a share of the mining income to the local budgets automatically using the formulas based on the objective indicators such as amount of population, amount of budget receipts from the area, poverty rate or geographical position. It has been identified that the basic principle of the system of resource use taxation to provide social welfare is represented by the optimal taxation scheme stimulating the production and maximizing the income which share is redistributed in favour of the society to cover all the local administration levels.
\end{abstract}

Originality. The comparative analysis and determination of the recent data of distribution of budget receipts from mineral resources in terms of the developing countries.

Practical implications. The obtained results may favour the scientific substantiation of the strategy to distribute mineral extraction revenue, planning of the development of mineral and raw material complex of the Central Asian countries; moreover, they may be useful while assessing the efficiency of investment projects of the field development.

Keywords: mineral resources, taxation, extractive industries transparency, distribution of taxes, budget receipts

\section{INTRODUCTION}

In the majority of countries where leaders in the development of natural resources are represented by state companies (Saudi Aramco, Saudi Arabia; ADNOC, UAE; Equinor/Statoil, Norway etc.), land and its minerals belong to the state (they are publicly owned). Certain political forces (state government, ruling political parties) and business-groups (co-owners of mining companies) use that fact as the key argument of the issue that the natural resource revenue is distributed in the interests of the country and the whole society. However, even lea- ding role of the state in redistribution of that revenue does not protect it from its privatization by specific social groups. Nevertheless, some countries have managed to solve the problem successfully. For instance, state oil companies of Kuwait and Yemen are owned by the ruling dynasties; however, as a result of natural resources redistribution, the countries could provide high living standards and social protection for their population and develop sustainable infrastructure (Couttenier \& Sangnier, 2015). Norway, the United Kingdom, the USA and other countries accumulate and redistribute conside-

(C) 2019. V. Churin, N. Vysotskaya, Yu. Sizova, E. Danilina, D. Gorelov. Published by the Dnipro University of Technology on behalf of Mining of Mineral Deposits. This is an Open Access article distributed under the terms of the Creative Commons Attribution License (http://creativecommons.org/licenses/by/4.0/), which permits unrestricted reuse, distribution, and reproduction in any medium, provided the original work is properly cited. 
rable amount of the revenue not only for the national needs but also for the development of social sphere and internal investments (Hinojosa, Bebbington, Barrientos, \& Addison, 2010). Though, in Venezuela, state monopoly for oil extraction has not eliminated overall poverty yet.

Natural resources play a dominating social, economic, and political role in 81 countries which cover a quarter of the world gross domestic product (GDP) and half of the world population (The World Bank Group, 2019). Taking into consideration that fact, transparency of the operations in mining industries is of special importance in the context of reporting to state agencies, high administration standards, and sustainable economic development (Piwniak, Bondarenko, Salli, Pavlenko, \& Dychkovskiy, 2007).

Extractive Industries Transparency Initiative (EITI) is one of the mechanisms favouring the transparency increase (Moses, Houqe, \& van Zijl, 2018). The countries, which have undertaken obligations to implement EITI standard, issue reports on the payments by mining companies to the state as well as on the payments declared by the state as the ones sent to the state budget. Thus, the process may be controlled by different interested parties state agencies, civil society, and company representatives.

According to the Initiative standard, citizens have an access to the information on tax and non-tax payments of the mining companies; that helps control their activity. Along with that, it favours positive investment climate taking into account the fact that transparency of that sector of economy allows investors reducing their risks to be sure in clear regulations while making decisions concerning the start of investments (Corrigan, 2017).

Mineral extraction revenue is distributed at the expense of taxation. Schemes for the taxation of extracted mineral resources depend upon the industry where a subsoil user operates, volume of the prospected minerals, and additional (specific) risks (Saik, Petlovanyi, Lozynskyi, Sai, \& Merzlikin, 2018). While determining the amount of natural and resource rent, we should take into account the volume of revenue and costs for the development and extraction as well as the index of normal profit of an investor considering reasonably estimated risks (Daniel, Keen, \& McPherson, 2010).

Specific risks of the mining industry involve: longterm period of geological prospecting and other exploratory operations; considerable volume of the initial irreversible investments into the deposit (since specific equipment aimed for the deposit will never be used again); uncertainty as for the future positive monetary flow from the raw material sell due to high volatility and unpredictability of prices; long-term period of operation below the breakeven point; possible negative effect of changes in political or environmental media; and considerable costs during the deposit development closure (Otto et al., 2006).

Taxation schemes vary considerably in the context of national risk components (political, sovereign, and legislative). Since the rate of normal profitability for some deposit investment project is higher for the country with high assessed risks, taxation scheme should offer additional tax benefits or reductions to compensate excess risks. At the same time, it is a widely used practice to apply increased royalty or tax rates for highly profitable deposits (Christmann \& Stolojan, 2001).

Optimal ratio of fiscal tools depends upon the possibilities and preferences offered by a specific country. Thus, taxation tools oriented to the extraction volume are convenient in terms of administration and provide stable budget receipts (Arabian countries, Mexico, some USA states). At the same time, they transfer key risks of the project implementation onto a subsoil user; as a response to that action, government reduces overall tax burden (Corporate income taxes..., 2012).

Other countries (Norway, France, Great Britain) apply more progressive taxation scheme (being oriented to the amount of income) by shifting the burden of risks to the state; in this case, comparatively high tax rate acts as a compensator (Land, 2010).

Apart from the general approach to the applied taxation scheme, certain external factors influence the selection of fiscal tools: overall economic dynamics (increase, recession, stagnation); extraordinary events changing ecological balance (natural disasters, technogenic accidents, catastrophes). Taking into consideration a multivariance of the approaches to the selection of certain taxation scheme, it is essential to analyze the evolution of approaches and schemes of mineral extraction taxation.

\section{TENDENCIES IN THE INTERNATIONAL PRACTICE IN TERMS OF MINERAL EXTRACTION TAXATION}

While generalizing international practice in the sphere of mineral extraction taxation, important tendencies being observed for the recent years should be analyzed:

1. Intensification of the international competitiveness (including tax one): gradual unbalanced recovery of the world economy after the 2008 - 2009 crisis has resumed the competitiveness for the potential investors between the developed countries and the ones with developing markets. Systematic decrease in the corporate income tax rate is one of the manifestations of that process. In terms of the countries rich in natural resources (Indonesia, Malaysia, Nigeria etc.), the mentioned tendency is accompanied by the reconsideration of the rates by means of special fiscal tools: royalty and rent taxes towards their growth which makes it possible to keep the budget in relatively balanced conditions (Issabayev \& Rizvanoghlu, 2019).

2 . Price rise in the world commodity markets in postcrisis period has allowed numerous countries (Columbia, Gabon etc.) increasing ad valorem rates as royalty as well as the royalty for the volume of the extracted raw material. Unequal price rise stipulates further differentiation of the tax rates and royalty depending upon the mineral type (Hogan, 2008).

3 . Under conditions of the economic growth and increased demand for mineral resources, countries with the developing markets (Brazil, Ghana, Indonesia etc.) use special fiscal tools as a key source of income. In this context, amount of tax incomes outsprips the economywide dynamics (Parcero \& Papyrakis, 2016).

Developed countries (the USA, Canada) try to reduce negative impact of the taxation of mineral extraction revenue by intensifying stimulating functions of universal fiscal tools (i.e. income tax), increasing neutrality of 
special fiscal tools (excess profit tax, royalty for income), and intensifying transparency of the process of tax payment by subsoil users and their administration by the authorized taxation bodies.

4. Beginning from 2010, popularity of the mixed taxation scheme (taking into account the extracted raw material and project profitability) is growing that makes it possible to minimize risks of state fiscal losses and risks of project attractiveness decrease due to the excessive taxation for an investor (Denmark, Norway, the Netherlands). Moreover, in federative countries (the USA, Canada), rent taxes become increasingly the revenue source not for central government but for local communities; thus, those payments become target ones (Van Alstine \& Barkemeyer, 2014).

5 . For the recent decade, a divergence between the developed countries and the countries with the develo- ping markets has been intensified as for objectives of mineral extraction taxation. Necessity in the additional financial resources for the budget of the countries with developing markets is the main problem of the "shortsightedness" of taxation policy and cause of using up mineral extraction profit that explains fiscal orientation of the mining taxation system in such countries (Vagonova \& Volosheniuk, 2012).

Enforcement of the rights for future generations as the main long-term non-fiscal taxation objective in the developed countries explains target nature of the mineral extraction revenue sent to so-called "wealth funds" (Hilson, 2012). Table 1 represents a list of the most important funds of that kind.

Thus, in terms of modern economic processes, a problem of fair and efficient distribution of mineral extraction revenue is of special importance.

Table 1. International stabilization funds formed at the expense of financial deductions from mineral extraction, at the end of 2016 (in the order of assets decreasing) (Sovereign wealth fund, 2019)

\begin{tabular}{|c|c|c|c|}
\hline Country & Fund name & Assets, bln USD & Resource \\
\hline \multicolumn{4}{|c|}{ State } \\
\hline Norway & State Pension Fund - Global & 1002.0 & Oil \\
\hline Kuweit & Kuwait Investment Authority & 642.0 & Oil \\
\hline Saudi Arabia & SAMA Foreign Holdings & 514.0 & Oil \\
\hline Qatar & Qatar Investment Authority & 320.0 & Oil \\
\hline Saudi Arabia & Public Investment Fund & 183.0 & Oil \\
\hline Iran & National Development Fund & 91.0 & Oil \\
\hline Russia & Russian National Wealth Fund & 76.3 & Oil \\
\hline Kazakhstan & Kazakhstan National Fund & 64.7 & Oil \\
\hline Brunei & Brunei Investment Agency & 40.0 & Oil \\
\hline the UAE (federal) & Investment Fund & 34.0 & Oil \\
\hline Azerbaijan & State Oil Fund of the Republic of Azerbaijan & 33.1 & Oil \\
\hline Oman & State General Reserve Fund & 18.0 & Gas \\
\hline Eastern Timor & Petroleum Fund of Timor-Leste & 16.6 & Gas \\
\hline Chile & Economic and Social Stabilization Fund & 14.7 & Copper \\
\hline Algeria & Revenue Regulation Fund & 7.6 & Oil \\
\hline Oman & Oman Investment Fund & 6.0 & Oil \\
\hline Mexico & Oil Revenues Stabilization Fund of Mexico & 6.0 & Oil \\
\hline Botswana & Pula Fund & 5.7 & Diamonds and minerals \\
\hline Angola & Fundo Soberano de Angola & 4.6 & Oil \\
\hline Columbia & Colombia Savings and Stabilization Fund & 3.5 & Oil and ore \\
\hline Kazakhstan & National Investment Corporation & 2.0 & Oil \\
\hline Nigeria & Nigeria Sovereign Investment Authority & 1.4 & Oil \\
\hline Iraq & Development Fund for Iraq & 0.9 & Oil \\
\hline Venezuela & FEM - Macroeconomic Stabilization Fund & 0.8 & Oil \\
\hline Ghana & Ghana Petroleum Funds & 0.45 & Oil \\
\hline Gabon & Sovereign Fund of the Gabonese Republic & 0.4 & Oil \\
\hline Mongolia & Fiscal Stability Fund & 0.3 & All minerals \\
\hline Mauritania & National Fund for Hydrocarbon Reserves & 0.3 & Gas \\
\hline \multicolumn{4}{|c|}{ Regional } \\
\hline The UAE, Abu-Dhabi & Abu-Dhabi Investment Authority & 828.0 & Oil \\
\hline The UAE, Dubai & Investment Corporation of Dubai & 209.5 & Oil \\
\hline The UAE, Abu-Dhabi & Mubadala Investment Company & 125.0 & Oil \\
\hline The UAE, Abu-Dhabi & Abu-Dhabi Investment Council & 110.0 & Oil \\
\hline The USA, Alaska & Alaska Permanent Fund & 64.9 & Oil \\
\hline Canada, Alberta & Alberta Heritage Savings Trust Fund & 13.4 & Oil \\
\hline The USA, Wyoming & Permanent Wyoming Mineral Trust Fund & 7.3 & All minerals \\
\hline The USA, Northern Dakota & North Dakota Legacy Fund & 4.3 & Gas \\
\hline The USA, Alabama & Alabama Trust Fund & 2.7 & Gas \\
\hline The USA, Utah & Utah-SITFO & 2.0 & Minerals \\
\hline The USA, Idaho & Idaho Endowment Fund Investment Board & 2.0 & Minerals \\
\hline The USA, Louisiana & Louisiana Education Quality Trust Fund & 1.3 & Gas \\
\hline Australia, Western Australia & Western Australian Future Fund & 0.3 & All minerals \\
\hline
\end{tabular}




\section{MODEL OF VERTICAL DISTRIBUTION OF TAX RECEIPTS FROM THE MINING INDUSTRIES}

Speaking about the distribution of tax receipts from the mining industries, it should be noted that despite different fiscal systems, many countries with high resource potential have developed methods to distribute local tax revenues. In the majority of cases, they mean lowered level of the government interference into the local budget administration and empowerment of the local authorities with the possibility to use rent payment and other revenues in the most efficient way - to satisfy the needs of local communities. Similar model of budget income distribution among all the levels of administration is known as a model of vertical distribution.

Following countries are among the ones which distribute tax revenues from the mining industries for the account of local authorities: Brazil, Ghana, Indonesia, Kazakhstan, Kyrgyzstan, China, Mongolia, the Philippines etc. Governments of those countries distribute budget revenues among all the local administration levels (vertical distribution) (Otto, 2000). Table 2 represents distribution of mineral taxes according to the levels of state administration. In Table 2 other sources of income, such as sales tax, dividends, and license payments are not included into the table.

Table 3 represents vertical distribution of budget revenues from the natural resources in the developing countries which distribute tax revenues from the mining industries for the account of local authorities.

Data of the tables show that in terms of the most countries, payments from mineral mining comes to the national-level institutions; however, they are distributed back to the mining areas and neighbouring territories. In this context, some countries (Brazil, Indonesia, the Philippines, Mongolia, Kyrgyzstan) send a share of revenues from mining to local budgets automatically using formulas based upon the objective indicators such as the amount of population, amount of budget receipts from the territories, poverty rate or geographical position.
Table 2. Distribution of mineral taxes according to the levels of state administration (Natural resource revenue sharing, 2016)

\begin{tabular}{|c|c|c|c|c|c|c|c|}
\hline \multirow[t]{2}{*}{ Country } & \multirow[t]{2}{*}{ State structure } & \multicolumn{2}{|c|}{ 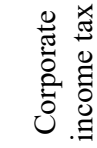 } & \multicolumn{2}{|r|}{$\frac{\gtrsim}{\frac{\pi}{\pi}}$} & \multicolumn{2}{|c|}{ 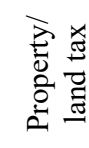 } \\
\hline & & $\mathrm{N}$ & $\mathrm{S}$ & $\mathrm{N}$ & $\mathrm{S}$ & $\mathrm{N}$ & $\mathrm{S}$ \\
\hline Argentine & Federal & $x$ & & & $x$ & & $x$ \\
\hline Australia & Federal & $\times$ & & $x^{*}$ & $x$ & $x^{*}$ & $x$ \\
\hline Brazil & Federal & $\times$ & & $\times$ & & $x$ & \\
\hline Canada & Federal & $\times$ & $\times$ & $x^{*}$ & $x$ & $x^{*}$ & $x$ \\
\hline Chile & Unitary & $\times$ & & & & $x$ & \\
\hline Chine & Regionalized unitary & $\times$ & & $\times$ & & $x$ & \\
\hline Congo & Unitary & $\times$ & & & $x$ & & $x$ \\
\hline Ghana & Unitary & $\times$ & & $\times$ & & $x$ & \\
\hline India & Federal & $\times$ & & & $x$ & & $x$ \\
\hline Indonesia & Regionalized unitary & $\times$ & & $x$ & & $x$ & $x$ \\
\hline Kazakhstan & Unitary & $\times$ & & & $x$ & & $x$ \\
\hline Kyrgyzstan & Unitary & $\times$ & & $x$ & & & $x$ \\
\hline Mexico & Federal & $\times$ & & $x$ & & $x$ & \\
\hline Mongolia & Unitary & $\times$ & & & $x$ & & $x$ \\
\hline Myanmar & Unitary & $x$ & & $\times$ & & $x$ & $x$ \\
\hline Peru & Unitary & $\times$ & & $x$ & $x$ & & $x$ \\
\hline the Philippines & Regionalized unitary & $x$ & $\times$ & $x$ & $x^{* *}$ & & $x$ \\
\hline Russia & Federal & $\times$ & $\times$ & $\times$ & & & $\times$ \\
\hline Southern Africa & Unitary & $\times$ & & $\times$ & & & $x$ \\
\hline Tanzania & Regionalized unitary & $\times$ & & $\times$ & & & $x$ \\
\hline the UAE & Federal & & $\times$ & & $x$ & & $x$ \\
\hline Great Britain & Regionalized unitary & $\times$ & & & & & \\
\hline the USA & Federal & $\times$ & $\times$ & $x$ & $x^{*}$ & & $x$ \\
\hline
\end{tabular}

Note:

$\mathrm{N}$ - national government;

$\mathrm{S}$ - sub-national administration (state, province, regional or municipal);

* - applied only within the territory of federal administration;

** - royalty are charged and excised only by the groups of indigenous community and some local authorities.

For instance, in Mongolia, most revenues from mining and oil sector are centralized; however, separate development funds operate for each city, town or region.

Table 3. Vertical distribution of budget revenues from natural resources in the developing countries (Natural resource revenue sharing, 2016)

\begin{tabular}{|c|c|c|c|c|c|c|}
\hline \multirow{2}{*}{ Country } & \multirow{2}{*}{ Resource } & \multirow{2}{*}{ Revenue stream } & \multirow{2}{*}{$\begin{array}{c}\text { National } \\
\text { government }\end{array}$} & \multirow{2}{*}{$\begin{array}{l}\text { Governing bodies in } \\
\text { the mining territories }\end{array}$} & \multicolumn{2}{|c|}{ Municipal/district governments } \\
\hline & & & & & producing & non-producing \\
\hline \multirow[b]{2}{*}{ Brazil } & Oil (apart from off-shore) & Rent & $12.6 \%$ & $52.5 \%$ & $26.2 \%$ & $8.7 \%$ \\
\hline & Oil (apart from off-shore) & $\begin{array}{l}\text { Special participa- } \\
\text { tion (some fields) }\end{array}$ & $50.0 \%$ & $40.0 \%$ & $10 \%$ & $0 \%$ \\
\hline \multirow[t]{2}{*}{ Ghana } & Minerals & Royalties & $91.0 \%$ & - & $9 \%$ & $0 \%$ \\
\hline & Oil & All & $84.5 \%$ & $3.1 \%$ & $6.2 \%$ & $6.2 \%$ \\
\hline \multirow[t]{2}{*}{ Indonesia } & Gas & All & $69.5 \%$ & $6.1 \%$ & $12.2 \%$ & $12.2 \%$ \\
\hline & Minerals & Royalties & $20.0 \%$ & $16.0 \%$ & $32 \%$ & $32 \%$ \\
\hline The Philippines & Minerals & All & $60.0 \%$ & $8.0 \%$ & $\begin{array}{c}18 \% \text { municipality; } \\
14 \% \text { barangay }\end{array}$ & $0 \%$ \\
\hline
\end{tabular}

In 2016, the Local Development Fund (LDF) was established there; the Fund received royalty from the mining industry as well as the payments for issuing mining licenses from the corresponding regions. At the same time, at the level with the representatives of administrate units, the LDF is responsible for making decisions concerning the funds administration.
Slightly different situation is observed in Kazakhstan where tax revenue from oil sector is administered by the National Fund while tax payments from the mining industry are controlled by national and local state institutions without any special procedures.

Kyrgyzstan also distributes financial revenues from the mining industries between national and local budgets. 
However, apart from standard taxes from mining activity, local authorities also obtain a package of social benefits; in some cases, company may offer local communities additional compensations including monetary payments.

Alaska has managed to harmonize versatile interests of the center and regions as well as business-structures and regional community. The experience is considered to be unique since a particular region of the country has managed to provide rather high level of common wealth mostly owing to the well-balanced and reasonable social and economic rent policy.

Corresponding system of the mineral use taxation is the important constituent of the mechanism to provide social welfare as a result of income redistribution.

There are following taxes at the territory of the state (Alaska's oil and gas..., 2012):

- mineral extraction tax - net profit from the extraction is subject to tax at the rate of $15 \%$ (in 2014, the tax reached $75 \%$ according to the progressive scale). The tax provides about $88 \%$ of the state income from the oil and gas extraction;

- royalty (compensation payment of the state for the right of natural resources ownership) - in the majority of cases, there is the rate of $12.5 \%$;

- property tax is $2 \%$ from the value of the property required for the field development; corporate tax is $9.4 \%$; environmental pollution charge during oil extraction is USD 0.05 for each barrel.

Major share of the tax payments is sent to the state budget (Common fund) to cover government expenditures. At the same time, $25-50 \%$ of the funds received owing to the resources taxation are sent to the specially established fund (Alaska Permanent Fund).

Basic principle of the taxation policy in terms of the income of the resource sectors of the economy is in the establishment of optimal rent climate which both stimulates the production and maximizes the income paid to the government (in the form of taxes).

In general, practice of the redistribution of rent income in the state of Alaska has its advantages and disadvantages (Bazaleva \& Kaznacheev, 2015).

Advantages include the establishment and efficient functioning of the special fund - Alaska Permanent Fund and the Constitutional Budget Reserve Fund. It was the establishment of those two Funds that made it possible to solve the problem of surplus profit redistribution (i.e. natural resource rent), accumulation of funds, and efficient management of the accrued capital.

Disadvantages of the practice demonstrated by Alas$\mathrm{ka}$ are in the development of maximally favourable tax scheme for enterprises (mostly, oil ones) which are tightly connected with the government. As a result, there are certain agreements between legislative power of the state and oil industry in favour of the latter.

Thus, the state of Alaska demonstrates economic and social efficiency of the system of natural resource rent receipt and use along with the unclear specification of the ownership rights with the following rent diffusion.

Below, there are examples of the developing countries when budget receipts obtained at the central level may be received locally within the areas they originate from or the neighbouring territories.

\section{DISTRIBUTION OF THE MINERAL EXTRACTION REVENUE IN TERMS OF THE DEVELOPING COUNTRIES}

\subsection{Kazakhstan}

In Kazakhstan, different institutions are responsible for tax administration. Kazakhstan National Fund regulates budget receipts from oil and gas sectors. In fact, that institution accumulates direct tax payments from the oil and gas sector; the payments account for $72.6 \%$ of the total state budget receipts (Natsional'nyy otchet..., 2017). In particular, the National Fund is established to ensure oil-selling revenues and balance national and regional budgets. Both the government and executive municipal bodies administrate budget receipts from the mining industry.

Reports on the expenditures of the National Fund as well as national and local budgets are published by the Ministry of Finances in statistic bulletins. Despite the fact that the government publishes the information on those financial operations, details concerning the formulas to calculate budget receipts distribution are not revealed. Moreover, changes are being constantly introduced into the tax rates. For instance, in 2011, mineral extraction tax was 7\%; however, in 2014, it was reduced down to $5 \%$. Basic local taxes paid by the subsoil users are as follows: emission tax, tax for the corporate vehicles, property tax, social tax, and land tax.

According to the report by the EITI of Kazakhstan (Natsional'nyy otchet..., 2017), in 2017, KZT 38.7 bln (USD $283 \mathrm{mln}$ ) were allocated for social and economic development of the regions by the subsoil users from oil and gas as well as mining industries; in this context, only oil and gas enterprises paid KZT 27.4 bln being almost USD $151 \mathrm{mln}(71 \%$ of the total amount). For instance, in 2017, Tengizchevroil - joint venture of Chevron, ExxonMobil, KazMunayGas, and LukArco paid out more than USD $372 \mathrm{mln}$ to the local budgets.

\subsection{Kyrgyzstan}

According to the report by the EITI of Kyrgyzstan (Otchet Kyrgyzskoy Respubliki..., 2015), in 2014, mining industry covered $8.4 \%$ of GDP. Moreover, in 2014, $40 \%$ of total export and $17 \%$ of total tax budget receipts accounted for mining industry.

According to the changes stipulated by the local government reform in 2012, authority and independence of local government bodies have increased considerably. In addition, new legislation on the distribution of budget receipts from the natural resources, adopted in 2013, has resulted in greater local financial receipts from the activities of mining enterprises. In 2014, the Regional Development Fund was established to develop local infrastructure and support different social and economic programmes.

Kyrgyzstan is divided into the regions consisting of districts; the districts are subdivided into communities (auls-aimaks). State budget functions at two levels: at the national level and at the level of auls-aimaks; due to that fact, they have their considerable responsibilities in terms of the expenses.

National budget receives income tax, VAT, rent payment, bonuses, excises, customs duties, administra- 
tive fines, and state capital dividends. Taxes being sent automatically to the local territories include land and property taxes, administrative fines, and budget receipts from the municipal property administration. All the aulsaimaks receive $50 \%$ of the income tax from the selling in terms of inter-budgetary transfers. In addition, aulsaimaks, within which territory mining enterprises operate, receive $50 \%$ of rent payment from the mineral extraction (except gold, oil, and gas), 3\% of the licensure payment, and $3 \%$ of the auction payments (Otchet Kyrgyzskoy Respubliki..., 2015).

In addition, companies operating within the regions with rich resources, pay $2 \%$ rent payment known as the "payment for the development and support of local infrastructures". That payment is distributed among certain auls-aimaks (20\%) and national budget (80\%) for further distribution among other auls-aimaks through the Regional Development Fund. In its turn, corresponding fund is divided into smaller funds in terms of regions and districts to support projects aimed at the development of communities. As a rule, objectives of those payments are to help the communities with economic progress and development of local infrastructure. Auls-aimaks rich in mineral resources and located within the territory of mining regions are given certain social support; in some cases, companies may offer local communities additional compensations including monetary benefits.

\subsection{Mongolia}

Mongolia is considered a significant world producer of gold, copper, and coal. 16.7\% of GDP is accounted for the mining industry. Major share of the revenues from mining and oil sector is centralized. In particular, government of the country receives rent payments from the mineral extraction and company income tax. Authorities of the regions and districts (aimaks) receive funds through the Common Local Development Fund (CLDF). The CLDF gets financing owing to the redistribution of the share of state budget income to support and provide sustainable local development. According to the report by the EITI of Mongolia, the Fund has several sources of income, i.e.:

$-5 \%$ of total VAT amount for goods and services (except the import);

$-5 \%$ of rent payment from the mineral extraction;

- grants and financial foreign aid to support local development;

- transfers from the lower-level budgets to the upperlevel budgets as well as $30 \%$ of rent payment from the oil sector (Mongolia twelfth EITI Report, 2018).

Besides, there are certain funds for the development of each town, city, region etc. It should be noted that local development funds receive finances allocated from the CLDF, additional revenues (accumulated at the expense of tax increase and cost saving), grants and donations from foreign funders, $10 \%$ of the fund balance after rent payments transferring from the entities dealing with state projects implementation, and $50 \%$ of the payment for the licensure for exploration and development of mineral resources. Moreover, local authorities are involved in issuing the licensure - they are consulted with while issuing the licenses for mining activity.
According to the EITI of Mongolia in 2017, local development funds received the income of MNT $105.9 \mathrm{bln}$ (USD $53 \mathrm{mln}$ ) including $70.4 \%$ of VAT (rate of $25 \%$ ), $18.2 \%$ of the payment for mineral extraction licensure (rate of 5\%), and $5.9 \%$ of VAT for oil extraction (rate of 30\%) (Mongolia twelfth EITI Report, 2018).

Nevertheless, the approach is characterized by several disadvantages. In particular, the available system of distribution basing upon the amount of population has resulted in much higher level of funds allocation for the capital which is also considered to be the richest region.

In addition, the country has the Fund of Human Potential Development aimed at the accumulation of savings and additional reserves from the mining sector. The Fund has following sources of income (Mongolia twelfth EITI Report, 2018):

- dividends from the sale of the government stock of entities which have mining licenses;

$-65 \%$ of rent payments from the entities which extract mineral resources;

- net profit from the investments into the Fund.

\subsection{China}

Resource tax being a part of Chinese tax system and being collected from the subsoil users (Kuklina, Chzhu Syaotsin, Sun' Yuysyu, \& Se Tyan'chen, 2014) was introduced into the tax system of the People's Republic of China in 1984. Both business entities and individuals dealing with mineral extraction within the territory of the country (including the offshore zone of China) pay that tax. Initially, resource tax was collected only in case of coal, oil, and natural gas extraction. In 1988, the tax began to be collected from the iron ore extraction and, further, from the extraction of salt, non-ferrous metal ores, non-metal ores, rare earth elements etc. Cost (in case of oil and natural gas) or amount (for other minerals) is the taxation basis (Kuklina \& Gao Tsze, 2005).

Major share of the resource tax in the PRC is sent to regional budgets except the tax receipts from oil and natural gas extracted in the offshore zone of China - they are sent to the central budget. All the organizations and sole proprietors involved in mineral extraction and salt production within the territory of China are to pay resource tax (Sun' Yuy, 2010).

The tax rate is set for the weight/volume of the extracted minerals; it varies depending upon the type and development method (Table 4).

Table 4. Resource tax rates in the PRC (Tax on the use..., 2019)

\begin{tabular}{lc}
\hline \multicolumn{1}{c}{ Taxation object } & Tax rate \\
\hline Crude oil & $8.0-30.0 \mathrm{CNY} / \mathrm{t}$ \\
Natural gas & $2.0-15.0 \mathrm{CNY} / 1000 \mathrm{~m}^{3}$ \\
Coal & $0.3-5.0 \mathrm{CNY} / \mathrm{t}$ \\
Ferrous metal ores & $2.0-30.0 \mathrm{CNY} / \mathrm{t}$ \\
Non-ferrous metal ores & $0.4-30.0 \mathrm{CNY} / \mathrm{t}$ \\
Other non-metal ores & $0.5-20.0 \mathrm{CNY} / \mathrm{t} / 1000 \mathrm{~m}^{3}$ \\
Hard salt & $10.0-60.0 \mathrm{CNY} / \mathrm{t}$ \\
Liquid salt & $2.0-10.0 \mathrm{CNY} / \mathrm{t}$ \\
\hline
\end{tabular}

In 2010, China initiated reforms in the sphere of mining taxation stipulating gradual refuse to use tax rates from the extraction amount and introduction of ad valorem rates (ad valorem tax). Since November 1, 2011, 
ad valorem rates for oil and natural gas extraction has been introduced over the whole territory of China along with the abolishment of the specific excise collected while developing oil within the continental shelf (Shira, 2016). Within the structure of Chinese tax revenue, resource tax accounts for less than $1 \%$ being rather low index taking into account considerable resource potential of the PRC (Zhang, 2014).

However, Chinese practice as for the resource tax distribution to the different-level budgets may be applied in Russia. In terms of China, almost all the sum of tax in terms of hard minerals and carbohydrates extracted within the mainland is sent to regional budgets being additional source for territorial development. As for Russia, $100 \%$ of MET from widespread mineral deposits, $100 \%$ of MET from diamonds, $60 \%$ of MET from other types of minerals are sent to regional budgets. At the same time, federal budget receives $100 \%$ of MET from carbohydrates including natural gas and $100 \%$ of MET from the minerals of Russian continental shelf, exclusive economic zone beyond the RF territory. Thus, the majority (in money terms) of MET share is sent to the federal budget leaving rather small sums of tax receipts for the regions.

\section{CONCLUSIONS}

Comparison of the taxation practices of both developed and developing countries demonstrates that if in the USA tax receipts into regional budgets bypass federal center, in case of the developing countries (Mongolia, Kazakhstan, Kyrgyzstan) major share of the mineral extraction receipts is centralized being distributed immediately from the center. In our opinion, state budget receipts from the mineral extraction should be sent to the local budgets. Finally, financial resources go back to the mining regions; however, it is hard to say whether those funds correlate to the payments made by the companies operating in those regions. Simply stated, there is no direct correlation between the payments by a certain company into the state budget and final amount of funds received by the budget of a region, district or community within which territory that company operates.

Thus, analysis of the international practices to apply a mechanism of redistribution of mineral extraction income aimed at the improved social welfare allows drawing certain conclusions.

There are following principles of the efficiency of the system of mineral extraction revenue redistribution: specification of the ownership right of all the parties of economic relations within the civil (social) form of ownership for natural resources; support of the balance in the interests of the involved parties along with the prevention of domination of certain groups (if necessary, they may be even forced to operate for the purpose of social welfare); possibility of social control of the operation of all the institutions and elements of the system, access to the information on the results of their functioning.

Appropriate resource-use taxation system is the important component of the mechanism aimed at provision of social welfare as a result of redistribution of the mineral extraction revenues. Establishment of optimal tax climate, stimulating the production and maximizing the income which share is redistributed in favour of the society to cover all the local administration levels, is the basic principle of that system.

Government acts as a leader in the formation of the mechanism to distribute mineral extraction revenue. Specialized funds are the efficient tool of state policy, especially while solving the problem of funds accumulation and efficient administration of the accrued capital aimed at social welfare. Their detailed analysis may be rather prospective issue for further studies.

\section{ACKNOWLEDGEMENTS}

The authors are grateful for the support in conducting the research to Moscow Automobile and Road Construction State Technical University (MADI), Moscow Metropolitan Governance University (MMGU), Plekhanov Russian University of Economics, and MIREA - Russian Technological University Institute of Educational Technologies and Humanities.

\section{REFERENCES}

Alaska's oil and gas fiscal regime - a closer look from a global perspective. (2012). Juneau, Alaska: Alaska Department of Revenue.

Bazaleva, R., \& Kaznacheev, P. (2015). Osvoenie arkticheskogo shel'fa. Regulirovanie i nalogooblozhenie neftyanykh kompaniy v SShA, Rossii i Norvegii. Ekonomicheskaya Politika, 10(2), 110-132.

Christmann, P., \& Stolojan, N. (2001). Management and distribution of mineral revenue in PNG: facts and findings from the sysmin preparatory study a consultant's perspective. London, United Kingdom: World Business Council for Sustainable Development.

Corporate income taxes, mining royalties and other mining taxes: a summary of rates and rules in selected countries. (2012). London, United Kingdom: PricewaterhouseCoopers LLP.

Corrigan, C.C. (2017). The effects of increased revenue transparency in the extractives sector: the case of the Extractive Industries Transparency Initiative. The Extractive Industries and Society, 4(4), 779-787. https://doi.org/10.1016/j.exis.2017.03.004

Couttenier, M., \& Sangnier, M. (2015). Living in the garden of eden: mineral resources and preferences for redistribution. Journal of Comparative Economics, 43(2), 243-256. https://doi.org/10.1016/i.jce.2015.01.008

Daniel, P., Keen, M., \& McPherson, C. (2010). The taxation of petroleum and minerals: principles, problems and practice. London, United Kingdom: Routledge. https://doi.org/10.4324/9780203851081

Hilson, G. (2012). Corporate social responsibility in the extractive industries: experiences from developing countries. Resources Policy, 37(2), 131-137. https://doi.org/10.1016/j.resourpol.2012.01.002

Hinojosa, L., Bebbington, A., Barrientos, A., \& Addison, T. (2010). Social policy and state revenues in mineral-rich contexts. Mineral Rents and the Financing of Social Policy, 1-42. https://doi.org/10.1057/9780230370913.0010

Hogan, L. (2008). International minerals taxation: experience and issues. In IMF conference on Taxing Natural Resources: New Challenges, New Perspectives (pp. 1-28). Washington, United States.

Issabayev, M., \& Rizvanoghlu, I. (2019). Optimal choice between local content requirement and fiscal policy in extractive industries: a theoretical analysis. Resources Policy, (60), 1-8. https://doi.org/10.1016/i.resourpol.2018.11.018 
Kuklina, E.A., \& Gao Tsze. (2005). Ustoychivoe razvitie KNR i prirodopol'zovanie. Ekonomika $i$ Upravlenie Proizvodstvom, (15), 1-14.

Kuklina, E.A., Chzhu Syaotsin, Sun' Yuysyu, \& Se Tyan'chen. (2014). Nalogovaya politika stimulirovaniya innovatsiy kak faktor ekonomicheskogo rosta: kitayskiy put'. Upravlencheskoe Konsul'tirovanie, 2(62), 84-93.

Land, B. (2010). Capturing a fair share of fiscal benefits in the extractive industry. Transnational Corporations, $18(1), 157-173$. https://doi.org/10.18356/1f2a726f-en

Mongolia twelfth EITI Report 2017. (2018). Ulaanbaatar, Mongolia: Consortium of Hart Nurse Ltd and Ulaanbaatar Audit Corporation LLC.

Moses, O., Houqe, M.N., \& van Zijl, T. (2018). What is the economic value of the Extractive Industries Transparency Initiative (EITI) information disclosure? Journal of Contemporary Accounting \& Economics, 14(2), 216-233. https://doi.org/10.1016/j.jcae.2018.05.003

Natsional'nyy otchet "O realizatsii Initsiativy prozrachnosti deyatel'nosti dobyvayushchikh otrasley $v$ Respublike Kazakhstan za 2017 god". (2017). Astana, Kazakhstan: TOO "UHY SAPA Consulting".

Natural resource revenue sharing. (2016). New York, United States: The Natural Resource Governance Institute.

Otchet Kyrgyzskoy Respubliki za 2013 - 2014 gody. (2015). Bishkek, Kyrgyzskaya Respublika: Sekretariat IPDO.

Otto, J., Andrews, C.B., Cawood, F., Doggett, M., Guj, P., Stermole, F., \& Tilton, J. (2006). Mining royalties. A global study of their impact on investors, government, and civil society. Washington, United States: The World Bank. https://doi.org/10.1596/978-0-8213-6502-1

Otto, J.M. (2000). Mining taxation in developing countries. Golden, United States: Colorado School of Mines, UNCTAD.

Parcero, O.J., \& Papyrakis, E. (2016). Income inequality and the oil resource curse. Resource and Energy Economics, (45), 159-177.

https://doi.org/10.1016/j.reseneeco.2016.06.001
Piwniak, G.G., Bondarenko, V.I., Salli, V.I., Pavlenko, I.I., \& Dychkovskiy, R.O. (2007). Limits to economic viability of extraction of thin coal seams in Ukraine. Technical, Technological and Economic Aspects of Thin-Seams Coal Mining International Mining Forum 2007, 129-132. https://doi.org/10.1201/noe0415436700.ch16

Saik, P., Petlovanyi, M., Lozynskyi, V., Sai, K., \& Merzlikin, A. (2018). Innovative approach to the integrated use of energy resources of underground coal gasification. Solid State Phenomena, (277), 221-231. https://doi.org/10.4028/www.scientific.net/SSP.277.221

Shira, D. (2016). China's resource tax reform presents new opportunities and restrictions in the mining sector. China Briefing.

Sovereign wealth fund. (2019). Retrieved from https://en.wikipedia.org/wiki/sovereign wealth fund\#large st sovereign wealth funds

Sun' Yuy. (2010). Nalog za pol'zovanie resursami v KNR. Vestnik Yuzhno-Ural'skogo Gosudarstvennogo Universiteta. Seriya: Ekonomika i Menedzhment, 20(196), 1-9.

Tax on the use of natural resources. (2019). Retrieved from http://chinawindow.ru/china/legalinformation-china/chinesetaxation/resource-tax/

The World Bank Group. (2019). Extractive industries. [online]. Available at: https://www.worldbank.org/en/topic/extractiveindustries/overview

Vagonova, O.G., \& Volosheniuk, V.V. (2012). Mining enterprises' economic strategies as derivatives of nature management in the system of social relations. Naukovyi Visnyk Natsionalnoho Hirnychoho Universytetu, (2), 127-134.

Van Alstine, J., \& Barkemeyer, R. (2014). Business and development: changing discourses in the extractive industries. Resources Policy, (40), 4-16. https://doi.org/10.1016/j.resourpol.2014.01.006

Zhang, Z. (2014). Energy prices, subsidies and resource tax reform in China. Asia \& the Pacific Policy Studies, 1(3), 439-454. https://doi.org/10.1002/app5.46

\section{РОЗПОДІЛ ДОХОДІВ ВІД ВИДОБУТКУ КОРИСНИХ КОПАЛИН: ОГЛЯД МЖЖНАРОДНОГО ДОСВІДУ}

\section{В. Чурін, Н. Висоцька, Ю. Сізова, О. Даніліна, Д. Горєлов}

Мета. Вивчення основних принципів та умов ефективності системи перерозподілу доходів від видобутку корисних копалин, у тому числі в країнах з невисоким рівнем добробуту.

Методика. У дослідженні використаний метод якісного та кількісного аналізу наукової літератури, даних Інституту управління природними ресурсами (Natural Resource Governance Institute (NRGI)), національних звітів за стандартом Ініціативи прозорості видобувних галузей (Extractive Industries Transparency Initiative, IПДО), відкритих джерел у мережі Інтернет. Розглядалися режими оподаткування доходів від видобутку корисних копалин і найбільш їх важливі тенденції протягом останніх років. Досліджувався розподіл податків на корисні копалини за рівнями державного управління, а також вертикального розподілу бюджетних надходжень від природних ресурсів. Як об’єкт дослідження обрані країни, що розподіляють податкові надходження від видобувних галузей на користь органів місцевого самоврядування.

Результати. Встановлено, що для більшості країн платежі від видобутку корисних копалин надходять до інститутів загальнонаціонального рівня, однак розподіляються назад на місця видобутку або в довколишні райони. Відзначено, що деякі країни передають частину з доходів від видобувних галузей до місцевих бюджетів автоматично, використовуючи формули, що базуються на об'єктивних індикаторах, таких як кількість населення, обсяги бюджетних надходжень з території, рівень бідності або географічне положення. Виявлено, що основним принципом системи оподаткування використання ресурсів для забезпечення суспільного добробуту $є$ встановлення оптимального режиму оподаткування, що залишає стимули до виробництва i, в той же час, максимізує дохід, частина якого перерозподіляється на користь суспільства між усіма місцевими рівнями управління.

Наукова новизна полягає у порівняльному аналізі та виявленні особливостей новітніх даних розподілу бюджетних надходжень від природних ресурсів на прикладі країн, що розвиваються.

Практична значимість. Результати можуть сприяти науковому обгрунтуванню стратегії розподілу доходів від видобутку корисних копалин, плануванню розвитку мінерально-сировинного комплексу країн Серед- 
ньої Азії, а також можуть бути корисними при оцінці ефективності інвестиційних проектів освоєння родовищ корисних копалин.

Ключові слова: корисні копалини, оподаткування, прозорість видобувних галузей, розподіл податків, бюджетні надходження

\section{РАСПРЕДЕЛЕНИЕ ДОХОДОВ ОТ ДОБЫЧИ ПОЛЕЗНЫХ ИСКОПАЕМЫХ: ОБЗОР МЕЖДУНАРОДНОГО ОПЫТА}

\section{В. Чурин, Н. Высоцкая, Ю. Сизова, Е. Данилина, Д. Горелов}

Цель. Изучение основных принципов и условий эффективности системы перераспределения доходов от добычи полезных ископаемых, в том числе в странах с невысоким уровнем благосостояния.

Методика. В исследовании использован метод качественного и количественного анализа научной литературы, данных Института управления природными ресурсами (Natural Resource Governance Institute (NRGI)), национальных отчетов по стандарту Инициативы прозрачности добывающих отраслей (Extractive Industries Transparency Initiative (ИПДО)), открытых источников в сети Интернет. Рассматривались режимы налогообложения доходов от добычи полезных ископаемых и наиболее их важные тенденции на протяжении последних лет. Исследовалось распределения налогов на полезные ископаемые по уровням государственного управления, а также вертикального распределения бюджетных поступлений от природных ресурсов. В качестве объекта исследования выбраны страны, которые распределяют налоговые поступления от добывающих отраслей в пользу органов местного самоуправления.

Результаты. Установлено, что для большинства стран платежи от добычи полезных ископаемых поступают в институты общенационального уровня, однако распределяются обратно на места добычи или в близлежащие районы. Отмечено, что некоторые страны передают часть с доходов от добывающих отраслей в местные бюджеты автоматически, используя формулы, которые базируются на объективных индикаторах, таких как количество населения, объемы бюджетных поступлений с территории, уровень бедности или географическое положение. Выявлено, что основным принципом системы налогообложения использования ресурсов для обеспечения общественного благосостояния является установление оптимального режима налогообложения, что оставляет стимулы к производству и, в то же время, максимизирует доход, часть которого перераспределяется в пользу общества между всеми местными уровнями управления.

Научная новизна заключается в сравнительном анализе и выявлении особенностей новейших данных распределения бюджетных поступлений от природных ресурсов на примере развивающихся стран.

Практическая значимость. Результаты могут способствовать научному обоснованию стратегии распределения доходов от добычи полезных ископаемых, планированию развития минерально-сырьевого комплекса стран Средней Азии, а также могут быть полезны при оценке эффективности инвестиционных проектов освоения месторождений полезных ископаемых.

Ключевые слова: полезные ископаемые, налогообложение, прозрачность добывающих отраслей, распределение налогов, бюджетные поступления

\section{ARTICLE INFO}

Received: 23 November 2018

Accepted: 2 May 2019

Available online: 6 May 2019

\section{ABOUT AUTHORS}

Vladimir Churin, Candidate of Philosophical Sciences, Associate Professor of the Department of Sociology and Management, Moscow Automobile and Road Construction State Technical University, 64 Leningradsky Ave., 125319, Moscow, Russian Federation. E-mail: churinvv@yandex.ru

Nataliya Vysotskaya, Doctor of Economic Sciences, Professor of the Department of Public Administration and Personnel Policy, Moscow Metropolitan Governance University, 28 Sretenka St, 107045, Moscow, Russian Federation. E-mail: vyssotsk@mail.ru

Yulia Sizova, Candidate of Economic Sciences, Senior Lecturer of the Department of Foreign Languages No. 1, Plekhanov Russian University of Economics, 36 Stremyanny Lane, 117997, Moscow, Russian Federation. E-mail: Sizova.YS@rea.ru

Elena Danilina, Doctor of Economic Sciences, Professor of the Department of Organizational and Personnel Work in Government, MIREA - Russian Technological University, 78 Vernadsky Ave., 119454, Moscow, Russian Federation. E-mail: danilina05@mail.ru

Dmitry Gorelov, Candidate of Economic Sciences, Associate Professor of the Department of Management, Institute of Educational Technologies and Humanities, 2/2 Malaya Pochtaya Str Bld. 8, 105005, Moscow, Russian Federation. E-mail: gorelovdv1988@mail.ru 